\title{
Interest ferments in yeast genome sequence
}

Paris. The first complete sequence of the genome of a eukaryote, the yeast Saccharomyces cerevisiae, will be achieved this week with the release of the final portion of the sequence by the European-led consortium of 96 laboratories - including some in the United States, Japan and Canada involved in the Yeast Genome Project.

The yeast genome is made up of 12.06 million bases distributed among 16 chromosomes, and contains around 6,000 genes. It is about 250 times smaller than the human genome. The availability of the entire yeast genome will provide unprecedented information about the architecture of a eukaryote genome, according to André Goffeau of the Universite Catholique de Louvain in Belgium, who is the coordinator of the Yeast Genome Project.

This has already shown that the yeast genome is much more densely covered with genes than expected, says Goffeau, while much of it is also redundant, with repeated sequences on various chromosomes. Waves and troughs of G-C rich and poor areas also occur on all the chromosomes. Both features must have evolutionary significance, he adds, while the G-C waves may also be

\section{IMAGE UNAVAILABLE FOR COPYRIGHT REASONS}

Brewing up: sequencing of the yeast genome follows the first genetically engineered beer recently launched in Britain.

important for replication. The sequence of the telomeres of all the yeast chromosomes is also unexpectedly similar.

The complete inventory of the yeast genome has also revealed a surprising number of both unknown genes - amounting to around one-third of the 6,000 genes identified in its genome - and new members of known protein families. For example, more than 20 putative sugar transporters, identified on the basis of their $\overrightarrow{0}$ transmembrane spans, have been found.

Clusters of proteins with similar structures, but no homology to known proteins, also occur. "We are discovering that there are many more protein families than we thought," says Goffeau. Discovering the

$\sim$ function of these unknown proteins will be the aim of a new European Union programme, EUROFAN, which will receive ECU7.7 million (US\$9.6 million) over the next two years. The programme will involve 144 laboratories.

The level of homology of yeast genes with human genes is also "striking", says Goffeau, who predicts that as many as half the yeast genes will be "significantly similar" to human genes. Many code for proteins involved in human diseases, and may open the way for the mechanisms of such pathologies to be studied within yeast, a much simpler alternative to doing so in human cells.

Bruno Hansen, head of life sciences at the European Commission, and former vicepresident of research at Novo Nordisk, predicts that this high level of homology also means that the results of the yeast genome project will play a major role in underpinning progress in the understanding of the

\section{AIDS advisers disagree over events in HIV blood scandal}

Tokyo. After the Japanese government's recent admission of its failure to prevent the infection of thousands of haemophiliacs with HIV in the early to mid-1980s, two parliamentary committees last week heard testimony from three scientists involved in deciding Japan's policy on blood products.

Their contradictory testimony, presented to the health and welfare committees of the upper and lower houses of Japan's Diet, raised more questions than answers. But it did provide some insight into the decisions and actions of these policy-makers.

The three were Takeshi Abe, former vice president of Teikyo University, who headed an AIDS study group established by the Ministry of Health and Welfare in 1983; Atsuaki Gunji, a professor at Tokyo University medical school, who headed the ministry's biologics and antibiotics division from 1982 to 1984 and setup the study group; and Juzo Matsuda, an assistant professor of Teikyo University, who was a member of the study group.

It was this study group and its subcommittee that recommended in 1983 that haemophiliacs should continue to use blood coagulants that had not been heat-treated to kill viruses, and which is said to have rejected a proposal for emergency imports of heat-treated products. Instead, clinical trials of heat-treated products were recommended and were carried out between 1984 and 1985 , coordinated by Abe.
Abe and Gunji, who testified separately and have previously given conflicting accounts of the events in question, failed to agree on the purpose or role of the AIDS study group. Abe claimed that its role was chiefly to determine whether there were any AIDS patients in Japan, and insisted that the group had only an advisory academic and scientific purpose and played no part in setting administrative policy.

But Gunji argued that the group's purpose was to examine how haemophiliacs were being treated and to decide if any changes were necessary because of the AIDS epidemic. He added that, while the group was set up only with research funds and was not intended to have an administrative role, it ended up becoming a "very important decision-making" body.

Matsuda testified that the study group's decisions resulted in the spread of HIV being much wider and he apologised to haemophiliacs. But Abe refused to take any responsibility, saying that "there is no point in feeling responsible".

Abe was repeatedly asked at both hearings about allegations that he deliberately delayed clinical trials of heat-treated blood coagulants so that the Japanese blood product manufacturer Green Cross Corporation (Midori Juji) could catch up with US and European manufacturers in the development of such products. He was also quizzed about large donations that he received from
Midori Juji and other companies in the clinical trials for a foundation that he set up.

Abe said it was "ridiculous" to suggest that he delayed the clinical trials. $\mathrm{He}$ claimed that he received money from the companies, $¥ 10$ million (about US $\$ 100,000$ ) each, only between May and July 1983, before the clinical trials started. He said it was "insulting" to suggest any link between the donations and the trials

But Gunji testified that in "late 1983" he received several complaints from foreign blood product manufacturers that Abe was requesting money, and that these had asked if such behaviour was acceptable. Gunji said he therefore decided to "warn" Abe about his fund-raising.

Although it was not discussed at the hearings, it has been widely reported that Abe, angered by Gunji's warning, suspended organization of the clinical trials and their start was delayed for a month until February 1984 because Abe, at the time Japan's leading authority on haemophilia, was seen as the only person with the power and influence to assemble the necessary groups of patients for the trials.

Abe did, however, admit in his testimony that he urged Midori Juji, Japan's largest blood manufacturer, to make heat-treated products "as quickly as possible". He said that this was because the clinical trials could not be carried out without Midori Juji's products.

David Swinbanks 


\section{MRC faces negligence claims over growth hormone victims}

human genome. Indeed, Hansen says that the completion of the yeast genome will have a broad impact on biological research and development. "It has been money well spent for Europe's taxpayers," he says.

The European Union is also supporting the sequencing of another yeast, Schizosaccharomyces pombe, which has just three chromosomes. Scientists are looking forward eagerly to comparing the genomes of the two yeasts, as $S$. pombe is in some ways closer to humans than $S$. cerevisiae.

The completed sequencing of the yeast genome follows that which has already been accomplished of two prokaryotes, the 1.8 MB genome of Haemophilus influenzae and the $0.58 \mathrm{MB}$ of Mycoplasma genetalium.

Few deny that the completion of the yeast genome represents a major success for Europe, and vindicates its strategy of distributing the work among many laboratories in a tightly coordinated way. The sequencing of the first chromosome of yeast - chromosome III - in 1992 was accomplished by each European laboratory sequencing a predetermined portion of the chromosome. At the time, it was the first chromosome to be sequenced and the largest continuous sequence of DNA known (see Nature 357, 38 ; 1992).

This approach was subsequently extended to the whole genome, with individual chromosomes being attributed to groups of 15-20 laboratories, which in turn divided the work among themselves. All data was centralized at the Martinsried Institute for Protein Sequence in Germany.

But the efficiency of this network model cannot be measured simply by the rate of sequencing, says Hansen. He points out that the large number of scientists involved are not merely engaged in sequencing but are also carrying out their own research, thus multiplying the benefits. "Scientists at centralized sequencing facilities can be too removed from the real world of research", he claims.

Declan Butler
London. Britain's Medical Research Council (MRC) was in court last week facing allegations of negligence in the experimental treatment in the 1960s and 1970s of children using human growth hormone $(\mathrm{hGH})$ from the pituitary glands of people who had died.

The programme was discontinued in 1985 , after three patients who had undergone the treatment in the United States died from Creutzfeldt-Jakob disease (CJD). Later that year a new technique for manufacturing $\mathrm{hGH}$ by genetic engineering became available.

The High Court in London has now opened a hearing on eight of 17 cases of CJD contracted by individuals in the United Kingdom treated with hGH before 1985. All but one of the 17 have since died.

Families of the eight victims started legal action against both the MRC and the Department of Health after the latter turned down calls for a public inquiry. At issue is whether the MRC and the department owed a duty of care to the children undergoing hGH treatment and, if so, whether they were in breach of that duty.

The families allege that the two bodies were negligent in not taking into account evidence that CJD was transmissible, not ensuring that no pituitaries were taken from people suffering from neurological disease, and not using the safest method of extraction of the hormone.

The MRC began the hGH programme in 1957 and ran it until the Department of Health took over control in 1976. But the MRC continued to manufacture the hormone until 1980, while the Department of Health was setting up production facilities at the Centre for Applied Microbiology and Research at Porton Down.

\section{Italian researchers look for return of Ruberti}

Rome. Sunday's general election in Italy seems to have brought good news for Italian researchers, who are optimistic that they will find the new centre-left government more sympathetic to the needs of science than its recent predecessors - and the familiar figure of Antonio Ruberti once again as research minister.

Romano Prodi, the new prime minister, who is professor of economics at the University of Bologna, has previously said that he ranks science and higher education among his priorities (see Nature 375, 620; 1995). The quality of science in Italy is patchy, he said last year, and this must change. During the election campaign he named Ruberti as official candidate for the research minister post.

Ruberti, who is 69, will bring much- needed experience to the job. He was formerly Italy's research minister for the five years up to 1992, during which time he introduced some important legislation, including laws on the autonomy of universities. He then served for two years as European Union research commissioner.

Ruberti is well known as a supporter of basic research, as well as a believer in the importance of European collaboration. He says that, if appointed, he is keen to install appropriate structures for quality control of Italian research, and to increase the level of university autonomy
Between 1957 and 1980 the only source of the hormone was the pituitary glands of people who had recently died. "Demand for the human growth hormone increased because it was a successful treatment," says a spokesman for the MRC. Nearly 2,000 people received the hormone treatment.

Over the period when hGH was extracted from cadavers, nearly one million pituitary glands were used in the United Kingdom. Mortuary attendants removed the glands and at one stage "received a nominal fee of twenty pence per gland". This system was later changed and mortuary attendants were paid a flat rate for the extra work involved in removing the glands.

According to Hugh Fraser, former head of the Neuropathogenesis Unit at the Institute for Animal Health in Edinburgh - and an expert witness in the court case - a critical question the judge will have to decide is "what knowledge was in place and when".

As early as the late 1950 s, it was recognized that scrapie-like diseases (such as CJD) might be transmissible. Later it was shown that biopsy material taken from the brain of a patient with CJD induced a similar brain disease when injected into a chimpanzee.

Such information raised warning signals among researchers. In October 1976, for example, Alan Dickinson, then head of the Disease Studies Unit at the Agricultural Research Council's laboratory in Edinburgh, says he telephoned the MRC to inform them of potential risks in the procedure.

A spokesman for the MRC said last week that when the first evidence suggested the possibility of potential risks, it was investigated. "When the evidence became substantive, they stopped using it," he added.

Richard Nicholson, editor of The Bulletin of Medical Ethics, points out that doctors providing a drug or a hormone as a treatment have a duty to inform their patients of any known side-effects. "The question is, at what stage did the MRC know about these risks?", he says.

While acknowledging that contaminated hGH was the source of the CJD infection, the Department of Health and the MRC deny negligence. In a statement issued last week, the MRC says that many people recognize that no form of medical treatment is without risk, and denies that it was negligent in supporting and monitoring the trial.

Irwin Mitchell, the solicitors for the plaintiffs, say that the court's judgement will have a direct effect on a further 200 cases now pending that have been filed on behalf of those who have not developed CJD as a result of hGH treatment, but fear that they may do so.

Ruth Bell 